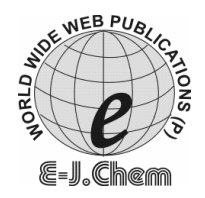

http://www.e-journals.net
ISSN: 0973-4945; CODEN ECJHAO

E-Journal of Chemistry

2009, 6(2), 371-376

\title{
Synthesis, Characterization and Antimicrobial Activity of Metal Chelates of 5-[1(H)-Benzotriazole methylene]-8-quinolinol
}

\author{
H.S.PATEL ${ }^{*}$ and K.K.OZA \\ Department of Chemistry, \\ Sardar Patel University, Gujarat, India. \\ hsp13152@rediffmail.com
}

Received 26 June 2008; Accepted 20 August 2008

\begin{abstract}
Chloromethyl-8-quinolinol was condensed stoichiometrically with benzotriazole in presence of potassium carbonate. The resulting 5-[1(H)-benzo triazole methylene]-8-quinolinol (BTMQ) was characterized by elemental analysis and spectral studies. The transition metal chelates viz. $\mathrm{Cu}^{2+}, \mathrm{Ni}^{2+}, \mathrm{Co}^{3+}$, $\mathrm{Mn}^{2+}$ and $\mathrm{Zn}^{2+}$ of BTMQ were prepared and characterized by metal-ligand (M:L) ratio, IR and reflectance spectral studies and magnetic properties. The antifungal activity of BTMQ and its metal chelates was screened against various fungi. The results show that all these samples are good antifungal agents.
\end{abstract}

Keywords: 1- $(H)$ Benzotriazole, 8-Quinolinol, Magnetic moment, Metal Chelates and Antifungal properties.

\section{Introduction}

8 -Hydroxyquinoline or 8 -quinolinol is well known as an analytical reagent ${ }^{1,2}$. Its various derivatives $^{3}$ are also useful in pharmaceuticals. Several azo dyes based on 8-quinolinol are also reported for dyeing of textiles as well as their chelating properties ${ }^{4,5}$. One of the derivatives, viz. 5-chloromethyl 8-quinolinol (CMQ) can be synthesize facilely and studied extensively for number of derivatives ${ }^{6}$. Some of the ions exchanging resins are also reported with good potentiality ${ }^{7-16}$. The literature survey reveals that the reaction of CMQ with 4 -substituted piperazine derivative has been reported recently ${ }^{17}$. One of the heterocyclic compounds such as 1-(H)-benzotriazole is found as an important heterocyclic compound. It's prime application is as corrosion inhibitors for copper or copper alloys ${ }^{18,19}$. Ciba Geigy has introduced benzotriazole derivative under the trade name Trinvin- $\mathrm{P}^{20}$. It is applied as an UV light absorber for stabilizing plastics and other organic materials against discoloration determination $^{20 .}$ It is also employed as photographic emulsion stabilizer ${ }^{21}$. In the peptide synthesis it acts in the form of an active ester ${ }^{22}$. If the 8-quinolinol introduced in the molecule of benzotriazole, the end molecule may play antimicrobial agent. Hence it was thought to study the benzotriazole and CMQ clubbed molecule. Thus the present paper comprises the synthesis, characterization, chelating properties and microbial activity of 5-[1(H)-benzotriazole methylene]-8-quinolinol (BTMQ) molecule. The reaction route is as shown in scheme. 


\section{Experimental}

5-Chloromethyl-8-quinolinol (CMQ) hydrochloride was prepared according to method reported in literature ${ }^{6 .}$ Benzotriazole was prepared by reported method ${ }^{23}$. All other chemicals used were of laboratory grade of purity.

Synthesis of 5-[1-(H)-benzotriazole methylene]-8-quinolinol.

\section{Formation of BTMQ}

In a round bottom flask, to a suspension of 5-chloromethyl-8-quinolinol (CMQ) hydrochloride $(23 \mathrm{~g}, 0.1 \mathrm{~mol})$ in dry acetone $(100 \mathrm{~mL}), 1-(H)$-Benzotriazole $(0.1 \mathrm{~mol})$ was added gradually at room temperature. Potassium carbonate $(16.8 \mathrm{~g})$ was added in the mixture and the mixture was refluxed on water bath for $8 \mathrm{~h}$. The resulting solid mass was add in to water and the precipitation was filtered off, washed with boiling water and the airdried. It was dark green amorphous powder. It was insoluble in common organic solvent but soluble only in formic acid and DMSO.

\section{Analysis}

Elemental analysis

$$
\mathrm{C}_{16} \mathrm{H}_{12} \mathrm{~N}_{4} \mathrm{O} \text { (276) }
$$

$\begin{array}{lllc} & \mathrm{C} \% & \mathrm{H} \% & \mathrm{~N} \% \\ \text { Calculated: } & 69.56 & 4.34 & 20.28 \\ \text { Found : } & 69.48 & 4.29 & 20.22\end{array}$

IR Features $\mathrm{Cm}^{-1}:$ 2980, 2850, $1470\left(\mathrm{CH}_{2}\right), 1630,1575,1500(8 \mathrm{HQ})$

NMR $\delta$ ppm : 5.85-8.3 (m $10 \mathrm{H} \mathrm{Ar-H}), 3.8(\mathrm{OH}) \quad 2.6\left(\mathrm{CH}_{2}\right)$

Synthesis of metal chelates of BTMQ

The metal chelates of BTMQ were prepared in two steps. All the metal chelates were prepared in an identical procedure. The details are given as follows.

\section{Preparation of BTMQ solution}

BTMQ (0.05 mol) was taken in $500 \mathrm{~mL}$ beaker. Formic acid was added up to slurry formation. To this slurry water was added till the complete dissolution of BTMQ. It was diluted to $100 \mathrm{~mL}$.

\section{Synthesis of BTMQ-metal-chelates}

In a solution of metal acetate $(0.005 \mathrm{~mol})$ in acetone: water $(50: 50 \mathrm{v} / \mathrm{v})$ mixture $(40 \mathrm{~mL})$, $20 \mathrm{~mL}$ of above mentioned BTMQ solution (i.e. containing 0.01 M BTMQ) was added with vigorous stirring at room temperature. The appropriate $\mathrm{pH}$ was adjusted by addition of sodium acetate for complete precipitation of metal chelate. The precipitates were digested on a boiling water bath. The precipitates of chelate were filtered off, washed by water and air-dried.

\section{Measurements}

The elemental contents of $\mathrm{C}, \mathrm{H}, \mathrm{N}$ were determined by TF-Flash-1101 EA, The metals contents of metal chelates were determined volumetrically by Vogel's method ${ }^{25}$. To a $100 \mathrm{mg}$ chelate sample, each $1 \mathrm{~mL}$ of $\mathrm{HCl}, \mathrm{H}_{2} \mathrm{SO}_{4}$ and $\mathrm{HClO}_{4}$ were added and then $1 \mathrm{~g}$ of $\mathrm{NaClO}_{4}$ was added. The mixture was evaporated to dryness and the resulting salt was dissolved in double distilled water and diluted to the mark. From this solution the metal content was determined by titration with standard EDTA solution. Infrared spectra of the synthesized compounds were recorded on Nicolet 760 FT-IR spectrometers. NMR spectrum of BTMQ was recorded on $400 \mathrm{MHz}$ NMR spectrophotometer. Magnetic susceptibility measurement 
of the synthesized complexes was carried out on Gouy Balance at room temperature. The electronic spectra of complexes in solid were recorded on at room temperature. $\mathrm{MgO}$ was used as reference. Antifungal activity of all the samples was monitored against various fungi, following the method reported in literature ${ }^{26 .}$

\section{Results and Discussion}

The synthesis of 5-[1-(H)-benzotriazole methylene]-8-quinolinol (BTMQ) was performed by a simple nucleophilic substitution reaction of 1-(H)-Benzotrizole and 5-chloromethyl-8quinolinol hydrochloride (CMQ). The resultant BTMQ ligand was an amorphous green powder. The $\mathrm{C}, \mathrm{H}, \mathrm{N}$ contents of BTMQ (Table 1) are consistent with the structure predicted (Scheme 1). The IR spectrum of BTMQ comprises the important bands due to 8-quinolinol. The bands were observed at $1630,1575,1470$, and $750 \mathrm{~cm}^{-1}$.

The broad band due to $-\mathrm{OH}$ group appeared at $3800-2700 \mathrm{~cm}^{-1}$. In this band the inflections are observed at 2950, 2920 and $2850 \mathrm{~cm}^{-1}$, while the latter two might be attributed to asymmetric and symmetric vibration of $\mathrm{CH}_{2}$ of CMQ. The NMR spectrum of BTMQ in DMSO indicates that singlet. The NMR spectrum of BTMQ in DMSO indicates that the singlet of $2 \mathrm{H}$ at $2.6 \delta \mathrm{ppm}$ of $\mathrm{N}-\mathrm{CH}_{2}-\mathrm{Ar}$ group. While the singlet at $3.8 \delta \mathrm{ppm}$ due to $-\mathrm{OH}$ group, the aromatic protons are appeared in multiplicity at $7.2 \delta$. The vigorous oxidation of BTMQ yield 8-hydroxy quinoline-5-carboxylic acid ${ }^{27}$ m.p. $230{ }^{\circ} \mathrm{C}$. Thus the structure of BTMQ is confirmed as shown in Scheme 1.

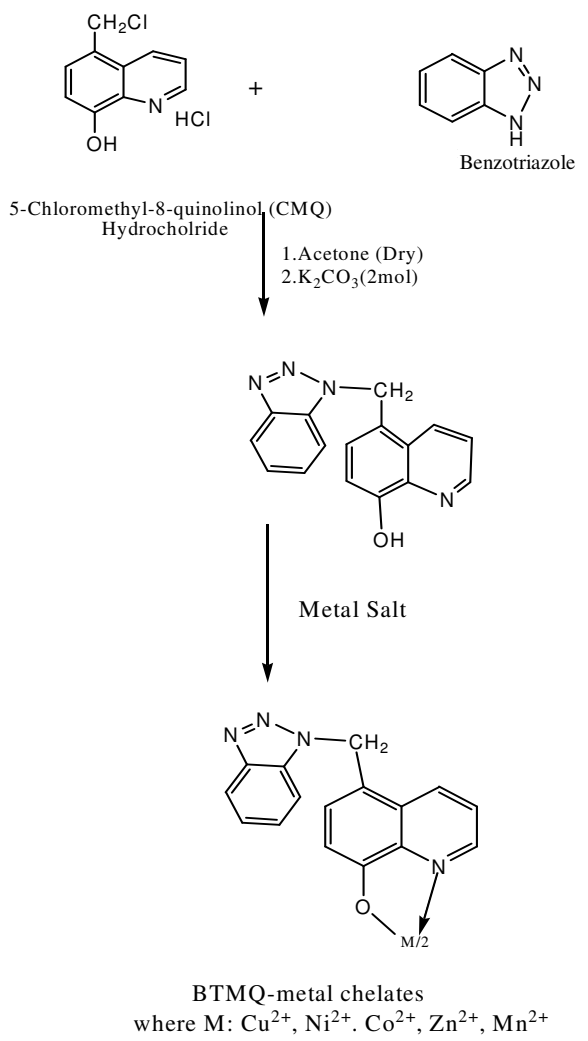

Scheme 1. 
The metal and $\mathrm{C}, \mathrm{H}, \mathrm{N}$ contents of metal chelates of BTMQ (Table 1) are also consistent with the predicted structure. The results show that the metal: ligand (M: L) ratio for all divalent metal chelate is 1:2.

Table 1. Analysis of BTMQ ligand and its metal chelates

\begin{tabular}{|c|c|c|c|c|c|c|c|c|c|}
\hline \multirow{3}{*}{ Empirical formula } & \multirow{3}{*}{\multicolumn{2}{|c|}{$\begin{array}{l}\text { Mol. Cal. Yield, } \\
\text { g/mole } \%\end{array}$}} & \multicolumn{7}{|c|}{ Elemental analysis, $\%$} \\
\hline & & & C & & & $\mathrm{H}$ & $\mathrm{N}$ & & $\mathrm{M}$ \\
\hline & & & Cald & Found & Cald & Founc & Cald & Found & Cald Found \\
\hline $\mathrm{C}_{16} \mathrm{H}_{12} \mathrm{~N}_{4} \mathrm{O}$ & 276 & 85 & 69.56 & 69.4 & 4.38 & 34.2 & 20.28 & 20.1 & ---- \\
\hline $\mathrm{C}_{16} \mathrm{H}_{12} \mathrm{~N}_{4} \mathrm{O} \mathrm{Cu}^{2+} 2 \mathrm{H}_{2} \mathrm{O}$ & 375.54 & 70 & 51.12 & 51.1 & 4.26 & 54.2 & 14.91 & 14.8 & 16.9216 .8 \\
\hline $\mathrm{C}_{16} \mathrm{H}_{12} \mathrm{~N}_{4} \mathrm{O} \mathrm{Ni}{ }^{2+} 2 \mathrm{H}_{2} \mathrm{O}$ & 370.96 & 65 & 51.75 & 51.7 & 4.31 & 4.2 & 15.09 & 15.0 & 15.8215 .8 \\
\hline $\mathrm{C}_{16} \mathrm{H}_{12} \mathrm{~N}_{4} \mathrm{O} \mathrm{Co}{ }^{2+} 2 \mathrm{H}_{2} \mathrm{O}$ & 370.93 & 70 & 51.76 & 51.7 & 4.31 & 4.3 & 15.09 & 15.0 & 15.8015 .7 \\
\hline $\mathrm{C}_{16} \mathrm{H}_{12} \mathrm{~N}_{4} \mathrm{O} \mathrm{Mn}{ }^{2+} 2 \mathrm{H}_{2} \mathrm{O}$ & 366.93 & 75 & 52.32 & 52.3 & 4.36 & 54.2 & 15.26 & 15.2 & 14.9714 .9 \\
\hline $\mathrm{C}_{16} \mathrm{H}_{12} \mathrm{~N}_{4} \mathrm{O} \mathrm{Zn}{ }^{2+} 2 \mathrm{H}_{2} \mathrm{O}$ & 377.39 & 65 & 50.87 & 50.8 & 4.23 & 4.2 & 14.83 & 14.7 & 17.3217 .3 \\
\hline $\mathrm{C}_{16} \mathrm{H}_{12} \mathrm{~N}_{4} \mathrm{O} \mathrm{Cd}^{2+} 2 \mathrm{H}_{2} \mathrm{O}$ & 424.41 & 75 & 45.23 & 45.2 & 3.76 & 53.6 & 13.19 & 13.1 & $26.48 \quad 26.3$ \\
\hline
\end{tabular}

The infrared spectra of all the chelates are identical and suggest the formation of the entire metalocyclic compound by the absence of band characteristic of free $-\mathrm{OH}$ group of parent BTMQ. The other bands are almost at their respectable positions as appeared in the spectrum of parent-BTMQ ligand. However, the band due to (M-O) band could not be detected as it may appear below the range of instrument used. The important IR Spectral data are shown in Table 2.

Table 2. Spectral features and magnetic moment of BTMQ metal chelates

\begin{tabular}{|c|c|c|c|c|c|}
\hline Metal Chelates & $\begin{array}{c}\mu_{\text {eff }} \\
(\mathrm{BM})\end{array}$ & $\begin{array}{c}\text { Electronic } \\
\text { spectral data, } \mathrm{cm}^{-1}\end{array}$ & Transition & \multicolumn{2}{|c|}{$\begin{array}{l}\text { IR spectral features common } \\
\text { for all, } \mathrm{cm}^{-1}\end{array}$} \\
\hline BTMQ-Cu ${ }^{2+}$ & 2.12 & $\begin{array}{l}23268 \\
15869\end{array}$ & $\begin{array}{l}\text { Charge transfer } \\
{ }^{2} \mathrm{~B}_{1 \mathrm{~g}} \rightarrow{ }^{2} \mathrm{~A}_{1 \mathrm{~g}}\end{array}$ & $\begin{array}{l}1630 \\
1575 \\
1500\end{array}$ & $\begin{array}{l}\text { Quinoline } \\
\text { moiety }\end{array}$ \\
\hline BTMQ $-\mathrm{Ni}^{2+}$ & 3.29 & $\begin{array}{l}22575 \\
15387\end{array}$ & $\begin{array}{l}{ }^{3} \mathrm{~A}_{1 \mathrm{~g}} \rightarrow{ }^{3} \mathrm{~T}_{1 \mathrm{~g}}(\mathrm{P}) \\
{ }^{3} \mathrm{~A}_{1 \mathrm{~g}} \rightarrow{ }^{3} \mathrm{~T}_{1 \mathrm{~g}}(\mathrm{~F})\end{array}$ & $\begin{array}{l}2980 \\
2850 \\
1470\end{array}$ & $\mathrm{CH}_{2}$ \\
\hline BTMQ - $\mathrm{Co}^{2+}$ & 4.65 & $\begin{array}{c}22733 \\
15255 \\
8921\end{array}$ & $\begin{array}{c}{ }^{4} \mathrm{~T}_{1 \mathrm{~g}}(\mathrm{~F}) \rightarrow{ }^{4} \mathrm{~T}_{2 \mathrm{~g}}(\mathrm{~F}) \\
{ }^{4} \mathrm{~T}_{1 \mathrm{~g}}(\mathrm{~F}) \rightarrow{ }^{4} \mathrm{~T}_{2 \mathrm{~g}} \\
{ }^{4} \mathrm{~T}_{1 \mathrm{~g}}(\mathrm{~F}) \rightarrow{ }^{4} \mathrm{~T}_{2 \mathrm{~g}}(\mathrm{P})\end{array}$ & $\begin{array}{c}1100 \\
500\end{array}$ & $\begin{array}{c}\text { C-O-M \& } \\
\text { O-M } \\
\text { bands }\end{array}$ \\
\hline BTMQ - $\mathrm{Mn}^{2+}$ & 5.40 & $\begin{array}{l}23870 \\
18337 \\
16821\end{array}$ & $\begin{array}{c}{ }^{6} \mathrm{~A}_{1 \mathrm{~g}} \rightarrow{ }^{6} \mathrm{~A}_{2 \mathrm{~g}}{ }^{4} \mathrm{E}_{\mathrm{g}} \\
{ }^{6} \mathrm{~A}_{1 \mathrm{~g}} \rightarrow{ }^{4} \mathrm{~T}_{2 \mathrm{~g}}(4 \mathrm{G}) \\
{ }^{6} \mathrm{~A}_{1 \mathrm{~g}} \rightarrow{ }^{4} \mathrm{~T}_{1 \mathrm{~g}}(\mathrm{PG})\end{array}$ & $\begin{array}{l}710 \\
750\end{array}$ & $\mathrm{Ar}-\mathrm{Cl}$ \\
\hline $\begin{array}{l}\text { BTMQ - } \mathrm{Zn}^{2+} \\
\text { BTMQ }-\mathrm{Cd}^{2+}\end{array}$ & $\begin{array}{l}\text { Diamag. } \\
\text { Diamag. }\end{array}$ & & -------- & ------ & ------ \\
\hline
\end{tabular}

Magnetic moments of metal chelates are given in Table 2. The diffuse electronic spectrum of $\mathrm{Cu}^{2+}$ chelates shows two broad bands around 13000 and $23000 \mathrm{~cm}^{-1}$. The first band may be due to a ${ }^{2} \mathrm{~B}_{1 \mathrm{~g}} \rightarrow{ }^{1} \mathrm{~A}_{1 \mathrm{~g}}$ transition. While the second band may be due to charge transfer, the first band shows structures suggesting a distorted octahedral structure for the $\mathrm{Cu}^{2+}$ metal chelates ${ }^{28-29}$. The higher value of the magnetic moment of the $\mathrm{Cu}^{2+}$ chelate supports the same. The $\mathrm{Co}^{2+}$ metal chelate gives rise to two absorption bands at 23800 and $19040 \mathrm{~cm}^{-1}$, which can be assigned ${ }^{4} . \mathrm{T} 1 \mathrm{~g} \rightarrow{ }^{2} \mathrm{~T}_{2 \mathrm{~g}},{ }^{4} \mathrm{~T}_{1 \mathrm{~g}} \rightarrow{ }^{4} \mathrm{~T}_{1 \mathrm{~g}}(\mathrm{P})$ transitions, respectively. These absorption bands and the $\mu_{\text {eff }}$ value indicate an octahedral configuration of the $\mathrm{Co}^{2+}$ metal chelate ${ }^{30-31}$. The spectrum of $\mathrm{Mn}^{2+}$ polymeric chelate comprised two bands at $19010 \mathrm{~cm}^{-1}$ 
and $23300 \mathrm{~cm}^{-1}$. The latter does not have a very long tail. These bands may be assigned to ${ }^{6} \mathrm{~A}_{1 \mathrm{~g}} \rightarrow$ ${ }^{4} \mathrm{~T}_{2 \mathrm{~g}(\mathrm{G})}$ and ${ }^{6} \mathrm{~A}_{1 \mathrm{~g}} \rightarrow{ }^{4} \mathrm{~A}_{2 \mathrm{~g}(\mathrm{G})}$ transitions, respectively. The high intensity of the bands suggests that they may have some charge transfer character. The magnetic moment is found to be lower than normal range. In the absence of low temperature measurement of magnetic moment it is difficult to attach any significance to this. As the spectrum of the metal chelate of $\mathrm{Ni}^{2+}$ show two sistint bands at 11960-11450 and 17700-17400 $\mathrm{cm}^{-1}$ are assigned as ${ }^{3} \mathrm{~A}_{2 \mathrm{~g}}(\mathrm{~F}) \rightarrow{ }^{3} \mathrm{~T}_{1 \mathrm{~g}}(\mathrm{~F})$ and ${ }^{3} \mathrm{~A}_{2 \mathrm{~g}}(\mathrm{~F}) \rightarrow$ ${ }^{3} \mathrm{~T}_{1 \mathrm{~g}}(\mathrm{~F})$ transition, respectively suggested the octahedral environment for $\mathrm{Ni}^{2+}$ ion. The observed $\mu_{\text {eff }}$ values in the range 3.01-3.2 B.M are consistent with the above moiety ${ }^{32-33}$.

The examination of antifungal activity of BTMQ ligand and its all chelates (Table 3) reveals that the ligand is moderately toxic against fungi, while all the chelates are more toxic than ligand. Among all the chelates the $\mathrm{Cu}^{2+}$ chelate is more toxic against fungi.

Table 3. Antifungal activity of BTMQ ligand and its metal chelates

\begin{tabular}{cccccccc}
\hline Sample & \multicolumn{7}{c}{ Zone of inhibition of fungus at 1000 ppm, \% } \\
\cline { 2 - 8 } & BT & N & RN & AN & AF & AA & AK \\
\hline BTMQ & 55 & 54 & 53 & 63 & 63 & 67 & 70 \\
BTMQ -Cu ${ }^{2+}$ & 83 & 78 & 77 & 83 & 81 & 81 & 85 \\
BTMQ -Zn ${ }^{2+}$ & 75 & 64 & 63 & 77 & 83 & 83 & 84 \\
BTMQ -Ni & & & \\
BTMQ -Co & 80 & 77 & 75 & 75 & 73 & 81 & 80 \\
BTMQ -Mn & 65 & 75 & 75 & 73 & 78 & 79 & 85 \\
BTMQ -Cd & 79 & 74 & 73 & 75 & 80 & 77 & 83 \\
\hline
\end{tabular}

$B T=$ Botrydeplaia thiobromine $N=$ Nigrospora Sp. $R N=$ Rhisopus Nigricans AN= Asperginus niger $A F=$ Aeprogines funigalus $A A=$ anida Albicans $A K=$ Andida krusegios candida grabrataHO5

\section{Acknowledgement}

The author thanks to Dr. J S. Parmar, HOD Department of Chemistry, Sardar Patel University, for providing research facility and encouragement

\section{References}

1. Raikhshtat M M, Savvin S B and Gribov L A, Zh Anal Khim., 1979, 34, 1886.

2. Gribov L A, Savvin S B and Raikhshtat M M, Zh Anal Khim., 1980, 35, 1469.

3. Oster K A and Golden M J, J Am Pharm Assoc Sci Ed., 1947, 37, 283.

4. Oster K A and Golden M, J Am Pharm Assoc Sci Ed., 1947, 37, 283.

5. Philips J P, Chem Review, 1984, 56, 271.

6. Barkhater J H and Teib R I, J Org Chem., 1968, 26, 4078.

7. Abraham W, Rani K, and Abrahaks P, U.S.Patent, 1976, 4317887.

8. Katshutoshi L and Hideki L, Japan Patent, 1998, 1017953.

9. Portanna T D, Anana, B P, and Rajvin Z A, Visokomol soedin, 1975, 17, 120.

10. Kenichiro A, Zaaea T and Sakurasaaea T Seni Gakkaiski, 2001, 57, 229.

11. Dunya A.D, Sukhina S.J, Sinyavskii V G and Kabrak Y P, Ukr Khim Zh., 1982, 48, 1087.

12. Xiamren C, Yushi F, Hisann L, Kazuhisa H and kusabbura A, Anal Sci., 1955, 11313.

13. Abraham A W, Abraham D and Rami K S, African Patent 1976, 7704289.

14. Den, J Appl Poly Sci., 1979, 24,14425.

15. Dem J, Reactive polymers, 1984, 2, 301.

16. Autkelav B, Eegochin E E, Mukhidinava B A and Ratikav S R, Vysokomal soedin ser., 1978, 220 A, 491.

17. Vohra I M, Ph D., Thesis, Veer Narmad South Gujarat University Surat, India. 
18. Long J W, Vecek L V, Sherwin-Williams Co U S, 1982, 4663914.

19. Hageolorn F and Evertz W, Bayer U S, 1984, 4424360.

20. Rahway N J, The Merk Index $11^{\text {th }}$ Ed Merk \& Co., 1981.

21. Ullman's Encyclopedia of Industrial Chemistry, Willey Veh., 1984, 26, 614.

22. Hadson D, River R C, Marshell G E, Peptides: Chem. \& Biology, 1990.

23. Vogel A.I, Textbook of Practical Organic Chemistry Pearson Education Ltd. New Delhi, $1^{\text {st }}$ Indian Edition, 2004.

24. Vogel A I Textbook of Quantitative Chemical Analysis, ELBS $4^{\text {th }}$ Ed., London, 1978.

25. Hathway B J and Tomilson A A G, Coord Chem Rev., 1970, 5,1.

26. Patil B R, J Indian Council of Chemists, 2006, 23, 01.

27. Hathway B J and Tomilson A A G, Coord Chem Rev., 1980, 36.

28. Pancholi H B and Patel M.M, J Polym Mater., 1996, 13, 261.

29. Papplardo R, J Chem Phy., 1960, 33, 613.

30. Lewis J and Wilkins R S, Modern Coordination Chemistry, New York, 1960, 290.

31. Furlani C and Morpurgo G, Theoret Chim Acta, 1965 1, 1181.

32. Jorgenson C K, Acta Chem Scand., 1955, 9, 1362. 


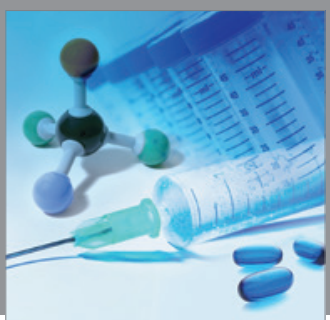

International Journal of

Medicinal Chemistry

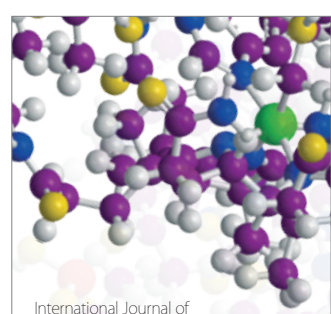

Carbohydrate Chemistry

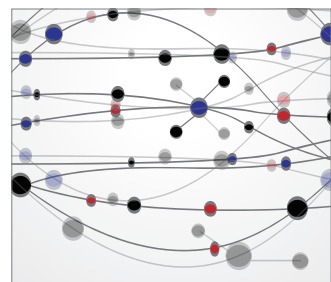

The Scientific World Journal
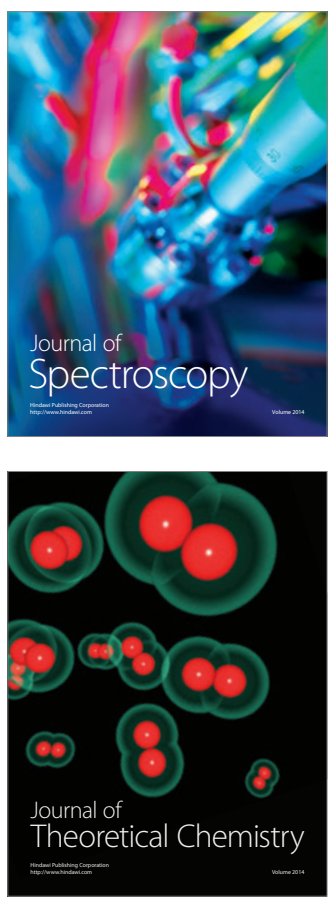
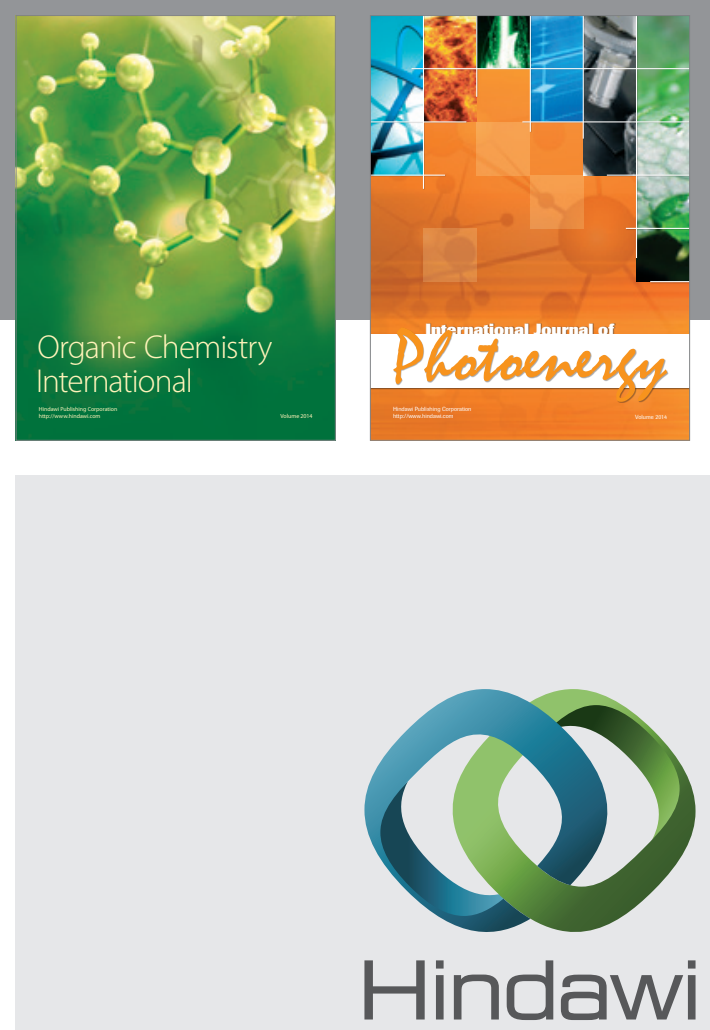

Submit your manuscripts at

http://www.hindawi.com
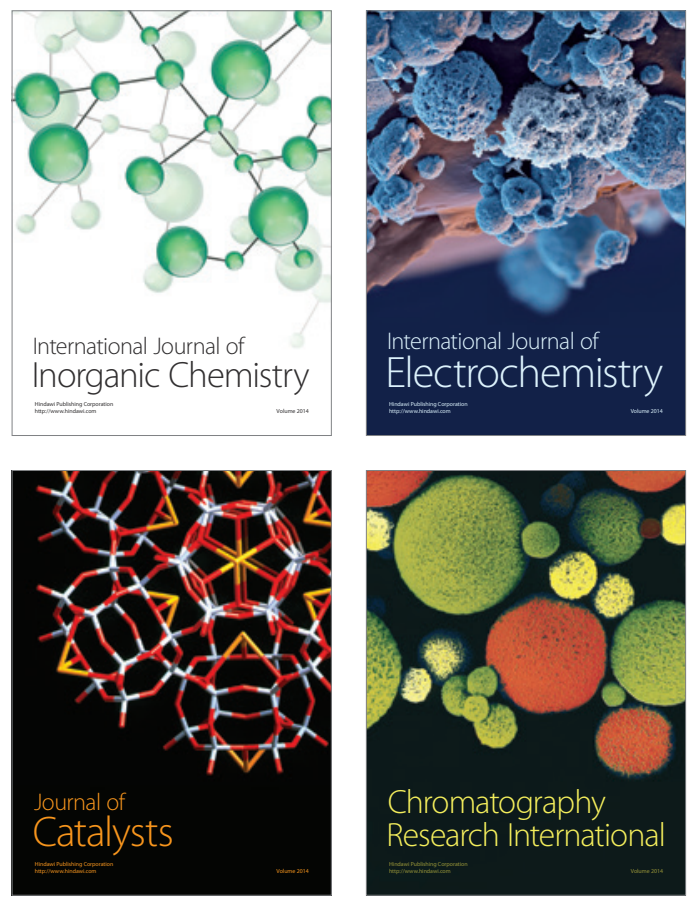
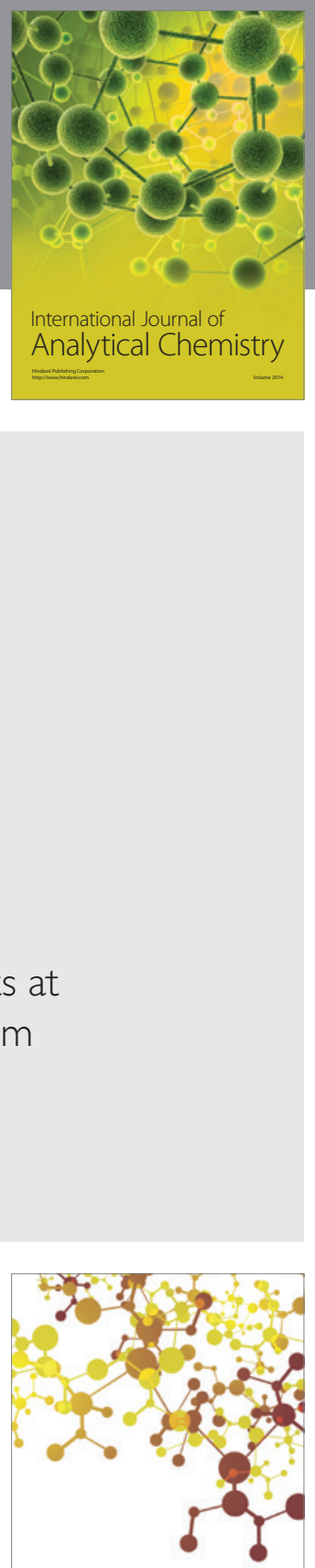

Journal of

Applied Chemistry
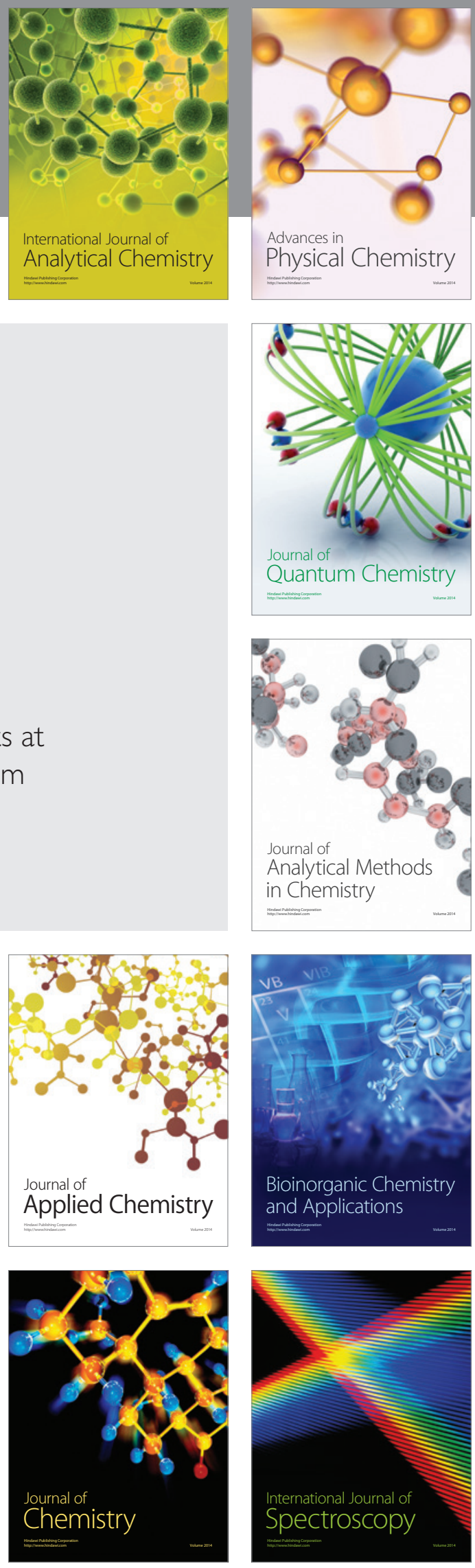